\title{
The United States Supreme Court
}

\section{and}

\section{North Carolina Obscenity Laws}

\author{
by Emily S. Boyce \\ Associate Professor \\ Department of Library Science \\ East Carolina University
}

The United States Supreme Court decision on obscenity in June, 1973 was the most significant ruling of the decade to directly affect librarians and educators. the ruling established a new set of guideines that would enable individual states to revise laws regarding the distribution of works with sexual content and allow states road latitude in defining what materials might be legally obscene.

of

The 1973 ruling grew out of a number of obscenity cases which reached the SuPreme Court at the same time. The action in the cases resulted in one decision by the Court. The decision involved a five to lour vote with Chief Justice Warren Burger Writing the majority opinion. The Court's uling requires states to define explicitly the kinds of sexual conduct described in Publications or pictured in media that will subject a publisher or distributor to prosecution.

Following such a definition, states may punish the printing or sale of works "which appeal to the prurient interest in sex, which portray sexual conduct in a patently offensive way and which, taken as a whole, do not have serious literary, artistic, political or scientific value." In judging whether a work appeals to prurient interest, a jury must apply the views of the average person, applying contemporary community standards rather than use the overturned standard as defined earlier in a 1966 Supreme Court decision.

In addition, the United States Supreme Court decision included the provision that trials on obscenity charges may properly admit expert affirmative evidence as to the character of the publication concerned. 
However, it is the person charged under the law who must prove that a challenged work has serious literary, artistic, political, or scientific value rather than the prosecutor, who had the legal responsibility under the 1966 obscenity ruling.

The widespread concern over the 1973 ruling prompted the American Library Association to join forces with other associations to form the Media Coalition. This new organization filed petitions with the Supreme Court requesting hearings for clarification of the obscenity ruling. These petitions were denied by the Court.

The vagueness of the ruling is illustrated in a recent action of the Supreme Court itself in the recent Jenkins vs. Georgia case. The Georgia Supreme Court found Billy Jenkins, a Georgia theater manager, guilty of violating the State's obscenity law for showing the film Carnal Knowledge. The United States Supreme Court overturned the conviction and in so doing was forced to admit that its provisions on community standards were at best vague and geographically mobile.

The Jenkins decision shows the continued confusion over interpreting the 1973 ruling, even by the Supreme Court itself. The vagueness of the term "community standards" forces the federal Supreme Court to continue in its role of defining "obscenity" on a case-by-case basis

In keeping with the Court's mandate to revise state laws to reflect the 1973 ruling, a bill was introduced in the 1973 session of the North Carolina legislature entitled: "An Act to Revise the North Carolina Anti-Obscenity Statute."

This act revised the North Carolina General Statute 14-190.1 which survived a test of constitutionality of the United States Supreme Court as recently as October 30, 1974.

According to the revised North Carolina obscenity law any material is obscene if it depicts or describes in a patently offensive way sexual conduct which is specifically defined in Section C of the act. If any person, applying contemporary statewide community standards relating to the depiction of representation of sexud matter, finds that the material taken as 0 whole appeals to prurient interest in sex there is foundation for an obscenity case.

Section 1 of the revision inserts the word "educational" in the list of redeeming adjectives in an effort to explain what may be obscene, saying if "the material lacks serious literary, artistic, political, edu' cational, or scientific value," the material is considered to be obscene.

Section 2 of General Statute 14-190.1 was revised in one important respect. A phrase was added at the end of the pro vision in part " $A$," so that it now reads as follows: "The purpose of this section is to provide an adversary determination of the question of whether books, magazines! motion pictures or other materials are $o b$. scene prior to their seizure or prior to 0 criminal prosecution relating to such $\mathrm{m}^{*}$ terials."

In other words the North Carolina obscenity law provides us with an adversary hearing prior to criminal action on the part of the courts. The importance of this provision cannot be overemphasized. The 1973 United States Supreme Court ruling failed to say that states must provide prior civil proceedings in obscenity cases, but North Carolina had this provision, in part, in its original law. THE FREEDOM TO READ FOUNDATION'S NEWS (Volume 3, Number 4, Summer, 1974) reports on this issue saying:

\begin{abstract}
"While rejecting restrictions on the freedom to read, we have contended that the restrictions now authorized by the Supreme Court require special safeguards in order to save certain fundamental constitutional rights, including the right of due process.

"We have said that, at the very least, our Constitution requires prior determination of obscenity through civil proceedings. That is, no criminal prosecutions of disseminators of communicative materials should be allowed unless there has been a prior determination of the illegality of the materials through proper judicial processes. Although prior civil proceedings will not eliminate bad laws, they can remove the pernicious element of vagueness."
\end{abstract}

North Carolina is one of the few states with provisions for an adversary hearing prior to a criminal prosecution. The legd 
Steps to be taken by law enforcement officials are outlined in the law, and it is of Paramount importance to understand these steps. Section C, G. S. 14-190.2 reads:

\begin{abstract}
"Whenever any law enforcement officer has reasonable cause to believe that any person, firm, or corporation is engaged in the sale, display, distribution, or dissemination in a public place of any books, magazines, motion pictures, or other materials which are obscene within the meaning of G. S. 14-190.1, he shall, without seizing such material, notify the solicitor for that district...."
\end{abstract}

Upon receipt of such notification from a law enforcement official, the solicitor of the judicial district then must submit a Written complaint to the resident judge and this complaint must fulfill the stated requirements of the law found in Section C 1-6.

After he receives the written complaint from the solicitor, the judge then issues a summons for the respondent to appear before him at a hearing in order to show cause why the said material should not be declared obscene.

The judge ultimately must render a decision on whether the material in question is obscene within a few days after the beginning of the hearing. In the event the iudge finds the material not to be obscene, the complaint is dismissed. If the judge finds the material to be obscene, he then issues a warrant to search for and seize the material. According to Section H, however, criminal proceedings still cannot begin unless the person, firm, or corporation continues to engage in the dissemination of the obscene material.

In summary, the first judgment of Whether a book, magazine, or other medi$\mathrm{Um}$ is considered obscene could rest with an average citizen. The second judgment is made by the law enforcement official who may or may not initiate legal action. The law states that all a police or sheriff's department official needs is "reasonable cause to believe...." If such a law enforcement official feels or thinks he has cause to believe the material is obscene, $h_{\theta}$ then files a complaint with the district solicitor or district attorney. After such a complaint is filed, the solicitor has no choice but to follow the law by submitting a complaint to the resident judge. The judge, in turn, also has no alternative but to continue to follow the law by initiating an adversary hearing regarding the complaint - the law states that the solicitor SHALL and the judge SHALL. The judgment to begin legal action rests with the law enforcement officer. In addition to law enforcement officials, the law permits district attorneys to initiate legal action.

Recently there was a controversy in Wilmington, North Carolina concerning a textbook used in advanced English classes. New Hanover County Sheriff H. G. Grohman filed a complaint with the district attorney which automatically initiated an adversary hearing to determine if the book entitled The Curious Eye was obscene. Superior Court Judge Joshua James ruled, on October 18, 1974, that the book had literary and educational value and was not obscene according to North Carolina law.

It is highly unlikely that any judge in this state will find any educational or library materials obscene due to the particular nature of the North Carolina obscenity law and because text materials and library books are selected for their educational value. Almost any district attorney will lament the fact that he has no choice or opportunity for judgment if a local law enforcement official files a complaint with him. Solicitors seem to feel strongly that they should have a choice before the law requires them to take the case to the district judge. They feel it is a waste of money for the state to prosecute many cases involving educational materials. According to district attorneys there is a readily discernible distinction between hardcore pornography which they feel should be prosecuted and materials that do not qualify as hard-core pornography.

In the past the library profession has devoted itself to the support of intellectual freedom. We have professed the right of an individual to read, view, and listen fo whatever he wishes as a right guaranteed by the United States Constitution. It has been our practice not to defend a specific 
title under censorship attack, but to defend the individual's right to read.

However, it is not the philosophy of intellectual freedom alone which is brought to trial in obscenity cases in the North Carolina courts, but specific book titles, magazines, and motion pictures. The court is concerned with the literary, artistic, political, scientific, educational, or other social value of the specific material being examined for alleged obscenity. This means professional librarians must be prepared to defend the title in court based upon sound interpretation of the law, and must be prepared to prove the material has merit as identified in that law.

The Wilmington case, cited earlier, presented some political aspects of an adversary hearing relative to school materials. Sheriff Grohman, after failing to remove allegedly objectionable materials through the legally prescribed method, stated that he would actively campaign against two school board members who opposed banning The Curious Eye, when they came up for re-election.

Librarians and educators also need to enter the political arena, if only by identifying the position of candidates for local boards of education as to their stand on the North Carolina obscenity law. It may mean identifying the position of the local candidate for sheriff as to his interpretation of the obscenity law in regard to school materials.

There is no doubt that librarians and educators in North Carolina will need to support the adversary hearing provision in the law if this provision is challenged in an effort to "tighten" the obscenity law in the next session of the legislature. If any changes are to be made in the present obscenity law it should be a "library exemption" provision which would protect all library-related materials from legal proceedings.

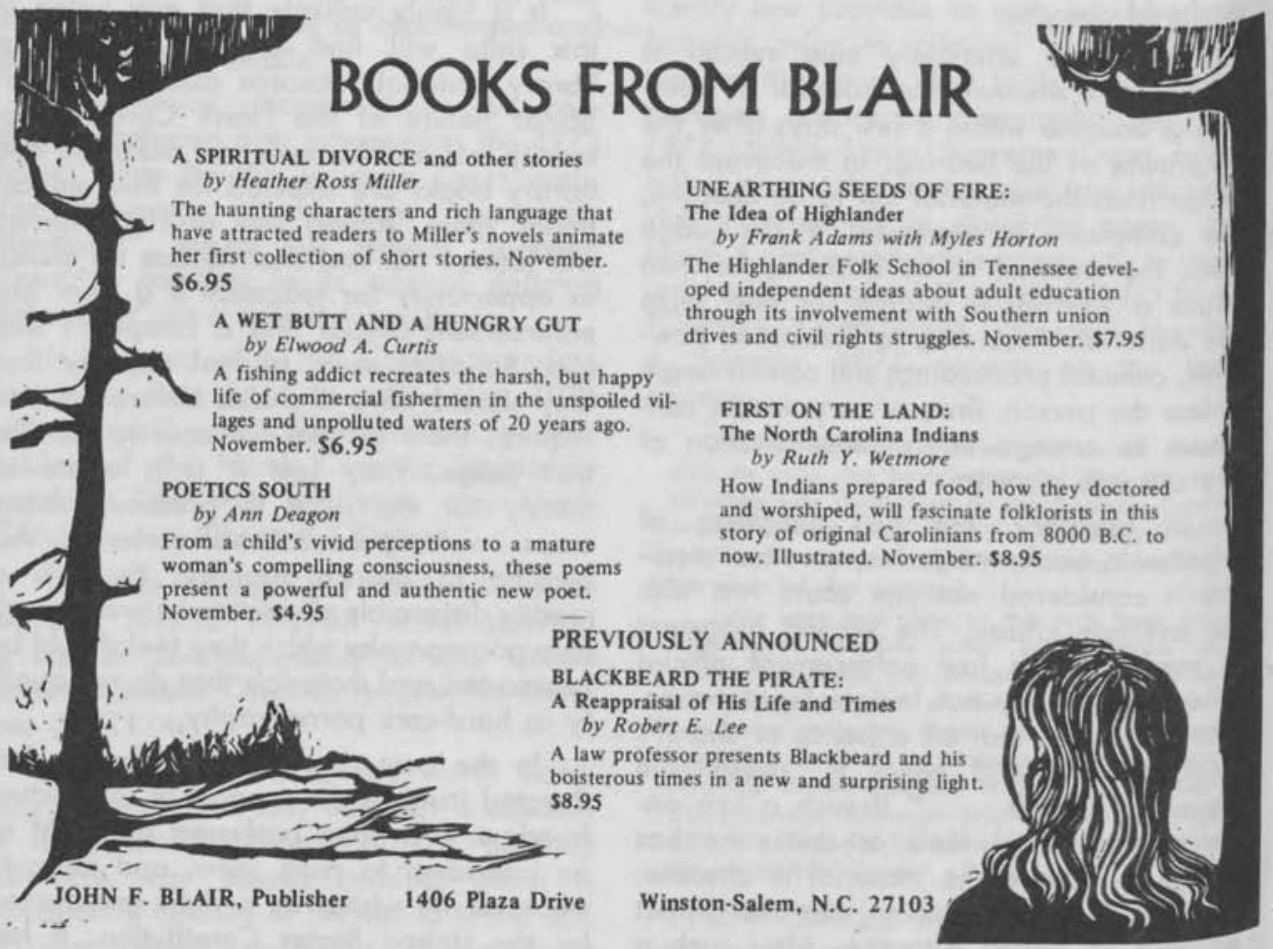

